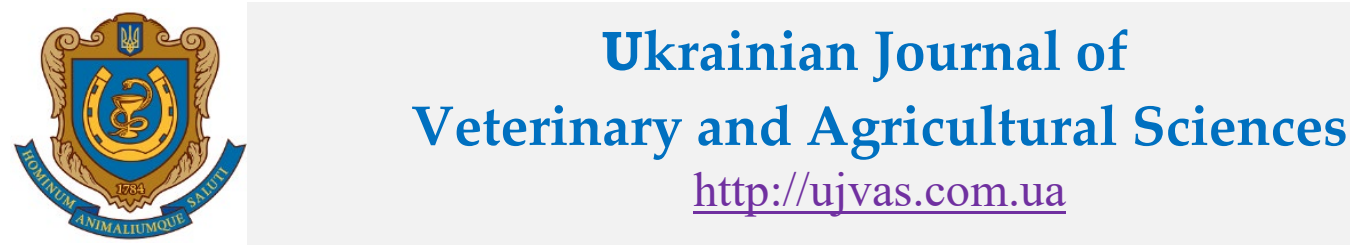

Stepan Gzhytskyi National University of Veterinary Medicine and Biotechnologies Lviv

\begin{tabular}{l|l|l} 
original article & UDC 619:581.4:616.391:636.5 & doi: 10.32718/ujvas3-3.02
\end{tabular}

Volume 3

Number 3

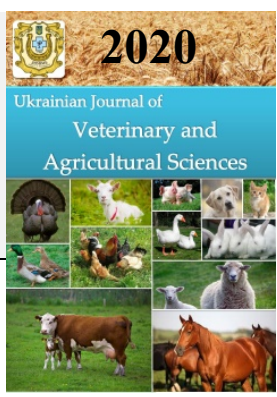

\title{
Prevention of hepatosis in laying hens using hepatoprotectors Hep-A- Stress and Hepasan-VS
}

\author{
V. Y. Yaremchuk, L. G. Slivinska \\ Stepan Gzhytskyi National University of Veterinary Medicine and Biotechnologies, Pekarska Str., 50, Lviv, 79010, Ukraine
}

\begin{tabular}{l} 
Article info \\
Received 02.07.2020 \\
Received in revised form \\
03.08.2020 \\
Accepted 04.08.2020 \\
\hline Correspondence author \\
Vasylyna Yaremchuk \\
Tel.: +38-063-649-99-20 \\
E-mail: vasulunkadunets@ukr.net \\
\hline 2020 Yaremchuk V., Slivinska L. \\
This is an open-access article \\
distributed under the terms of the \\
Creative Commons Attribution \\
License, which permits unrestricted \\
use, distribution, and reproduction \\
in any medium, provided the \\
original author and source are \\
credited.
\end{tabular}

(c) Er

Contents

1. Introduction

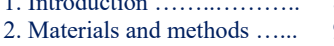

3. Results and discussion ....... 9

4. Conclusions ................. 14

References

\begin{abstract}
The article presents the results of preventive efficacy of hepatoprotectors Hep-A-Stress and Hepasan-VS in laying hens with hepatosis. The research was conducted in modern poultry farm. Three groups of laying hens (control and two experimental) Lohmann Brown breed $(n=1500)$ aged 224 days were formed. The poultry was kept on the main ration according to the technological map for the use of this breed. Laying hens from the first experimental group were additionally given hepatoprotector Hep-A-Stress and the second - Hepasan-VS. Blood sampling for the study was performed three times: before the start of drug administration, after 10 and 30 days from the beginning of hepatorotectors administration. The prophylactic effect of these drugs was determined by studying the preservation and productivity of poultry, interpretation of biochemical analysis of blood serum. The use of hepatoprotectors has allowed to increase the preservation and egg production of laying hens. The results of our studies showed insignificant changes of biochemical parameters in blood after 10 days administration of drugs, which indicates a slow effect of hepatoprotectors on the regenerative processes in the body of poultry. The prophylactic effect was established after 30 days use of hepatoprotectors. Our results showed that the use of these drugs had a positive effect on the protein-synthesizing function of the liver, as indicated by a decrease in serum total protein and an increase a albumin contents. There was also a positive effect on the intensity of protein metabolism, indicated by decreased uric acid and an increased urea in the blood serum of experimental groups. The use of hepatoprotectors helped to reduce the activity of hepatospecific enzymes AST and ALT, which indicates the stabilization of cellular structures of hepatocytes. These drugs have increased the function of bile secretion, which is key of lipid metabolism, as evidenced by an increase in serum cholesterol. Thus, the use of these hepatoprotectors has a positive effect on metabolic processes in the body of laying hens, in particular, normalizes liver function and prevents the development of hepatosis.
\end{abstract}

Key words: laying hens, metabolism, liver, blood serum, productivity, poultry preservation, enzymes, proteins.

\section{Citation:}

Yaremchuk, V. Y., \& Slivinska, L. G. (2020). Prevention of hepatosis in laying hens using hepatoprotectors Hep-A-Stress and HepasanVS. Ukrainian Journal of Veterinary and Agricultural Sciences, 3(3), 8-14.

\section{Introduction}

The dynamic growth of the number of poultry of all species is a feature of the current state of development of the poultry industry of Ukraine during the last decade (Mel'nyk \& Ponomar, 2014; Mel'nyk, 2015). Therefore, there is a need for effective control over the health of poultry and the timeliness of treatment and prevention measures (Sokolov, 2016; Dunets \& Slivinska, 2017).

Analyzing the research of recent years, it was found that liver disease is significantly more common among hens of egg productivity. In the structure of non-contagious diseases of poultry, according to a number of authors (Bessarov et al., 2009; Kal'berg \& Sadovnykov, 2010; Sokolov \& Ivannikov, 2013; Melnyk, 2014), liver pathology (hepatosis or hepatodystrophy, hepatitis and liver cirrhosis) are diagnosed in $5.0-50.8 \%$. Therefore, timely diagnosis of the functional state of the liver of laying hens is actual, as pathological processes of this organ lead to irreversible processes, the development of disease and death (Dunets \& Slivinslka, 2018; Ostapyuk \& Gutyj, 2019).

The use of drugs with different spectrum of action is widely introduced into the scientific and practical component of the poultry industry (Melnyk, 2017). Research on the impact of the development of liver pathologies on the productivity of poultry, which directly depend from the state of metabolic processes in the body, is gaining actual. Therefore, the study of comprehensive and deep mechanisms of biochemical processes regulation in the body of poultry using drugs of different directions, primarily having hepatoprotective and anti-stress properties (Zhang et al., 2008; Ermashkevich \& Kletikova, 2016).

The solution to the problem of normalization of metabolic processes in the poultry body and morphological and functional state of the liver with the use of hepatoprotective drugs is an important reserve for improving the efficiency of the poultry industry and production. It is necessary to improve the methods of early diagnosis of liver dysfunction 
(Kochish et al., 2004; Ezhkov, 2006; Sokolov \& Ivannikov, 2013).

The purpose of our research - to compare the influence and determine the hepatoprotective effect of drugs Hep-AStress and Hepasan-VS on the body of laying hens for prevention of hepatosis.

\section{Materials and methods}

The study was conducted in LLC (LIMITED LIABILITY COMPANY) Agrofirm "Zagai” of Kamiyanka-Buzkyi district of Lviv region and in laboratory of clinical and biological research of State Scientific-Research Control Institute of Veterinary Medicinal Products and Feed Additives.
To achieve set goal, three groups of laying hens (control and two experimental) of the Lohmann Brown breed $(n=1500)$ aged 224 days were formed. At the poultry farm the hens were keep in a typical room equipped with 5-tier batteries with feeders, planting density of 10 heads per cage.

Laying hens of control and experimental groups were kept on the main ration (MR) provided by the technological map for the use of this breed of poultry. The first experimental group hens were additionally given oral hepatoprotector Hep-A-Stress at a dose of $1 \mathrm{ml}$ per 1 liter of drinking water for 10 days, and the second experimental group - hepatoprotector Hepasan-VS at a dose of $1 \mathrm{ml}$ per 1 liter of drinking water for 10 days, using a dispenser (Table 1).

Table 1

Scheme of production-experimental researches using hepatoprotectors

\begin{tabular}{|c|c|c|c|c|}
\hline Animal groups & Scheme of researches & $\begin{array}{c}\text { The term of administration } \\
\text { of hepatoprotectors }\end{array}$ & $\begin{array}{l}\text { The term of } \\
\text { conducting } \\
\text { researches }\end{array}$ & $\begin{array}{l}\text { Age of poultry } \\
\text { (days) }\end{array}$ \\
\hline Control & The main ration & did not give & 30 days & 224 day \\
\hline Experimental 1 & $\begin{array}{l}\text { The main ration }+ \\
\text { Hep-A-Stress }(1 \mathrm{ml} / 1 \text { of water })\end{array}$ & 10 days & 30 days & 224 day \\
\hline Experimental 2 & $\begin{array}{l}\text { The main ration }+ \\
\text { Hepasan-VS ( } 1 \mathrm{ml} / \mathrm{l} \text { of water })\end{array}$ & 10 days & 30 days & 224 day \\
\hline
\end{tabular}

To establish the prophylactic efficacy, the preservation and egg productivity of the groups studied were evaluated. Daily egg laying was recorded by the number of eggs laid by each group of laying hens.

The material for the study was blood, obtained in vivo from the subclavian vein, in compliance with the rules of aseptic and antiseptic. Serum biochemical analysis was performed in 30 hens from each group. Blood sampling in laying hens for research was performed three times: before the start given of drugs (224 days), after (234 days) and after 30 days from the start after given hepatotectors (254 days).

Serum total protein content and its fractions, aspartate (AST) and alanine (ALT) aminotransferase activity, cholesterol level, urea concentration, uric acid were determined. The study was performed using a semi-automatic biochemical analyzer "HumaLyzer 3000" using Human Diagnostics Worldwide (Germany) reagents. The content of total protein was determined using an IRF-22 refractometer. The protein fractions in blood serum was determined by cellulose acetate electrophoresis using a Scan Power 300 and Scanion Lira 400 microprobe electrophoresis devices, Hospitex Diagnostics.

Experimental study was performed in accordance to bioethical standards in relation to animals that meet the requirements of the Law of Ukraine № 3447-4 "On protection of animals from cruel treatment", the provisions of European Convention for the Protection of Vertebrate Animals, used for Experimental and Scientific Purposes (Strasbourg, 1986).

The results of biochemical studies are presented in accordance with the International System of Units recommended for use in clinical laboratory practice. The analysis of research results was performed using a program package Statistica 6.0 software (Stat Soft, Tulsa, USA). Probability differences were assessed by Student's t-test.

\section{Results and discussion}

\section{Results}

During the examination of poultry, metabolic disorders were diagnosed, which accounted for $90 \%$ of pathologies of non-contagious etiology, and in $80 \%$ of cases liver diseases were diagnosed. In addition, the analysis of the age dynamics of hepatosis development in laying hens was performed (Dunets \& Slivinska, 2018). Due to the results of biochemical analysis of blood serum, it was found that the most favorable for the development of hepatosis were laying hens 300 and 530 days of age. However, the results of morphological examination of the liver indicate enlargement of organ and discomplexation of liver beams in $30 \%$ of poultry aged 166 days (Yaremchuk et al., 2020).

The analysis of the obtained data made it possible to determine the nature of metabolic pathology, to identify the subclinical course of hepatosis in laying hens and to apply preventive measures, the ultimate goal of which is preservation of poultry and increase of its productivity (Dunets \& Slivinska, 2018).

Influence of hepatoprotectors Hep-A-Stress and Hepasan-VS on the preservation of poultry is shown in Table 2. At the beginning of the study, the number of poultry in each group was the same. In 10 days after the beginning of the study, it decreased in the control group, the first and second experimental groups on $0.9 \%, 0.5 \%$ and $0.7 \%$, respectively. After drugs administration, the difference was $3 \%, 1.7 \%$ and $1.9 \%$, respectively, compared to the beginning of the study. The preservation of the control group of laying hens during our research was lower by $1 \%$ and $1.2 \%$ comparing to the experimental groups. 
Table 2

Preservation of laying hens during the period of the research $(n=1500)$

\begin{tabular}{|c|c|c|c|}
\hline Parameters & Control & Experimental 1 & Experimental 2 \\
\hline The number of poultry before the use of hepatoprotectors & 1500 & 1500 & 1500 \\
\hline The number of poultry after 10 days & 1487 & 1492 & 1490 \\
\hline The number of poultry after 30 days & 1456 & 1475 & 1472 \\
\hline Mortality for the period of research & 44 & 25 & 28 \\
\hline Preservation of poultry, $\%$ & 97.1 & 98.3 & 98.1 \\
\hline
\end{tabular}

During the experimental period, the number of eggs in the control and experimental groups was recorded daily, the results are presented in table 3 . It was established that during 10 days of the experiment 14070 eggs were received from 1500 laying hens of the control group with egg production of $93.8 \%$, in the first experimental group -14265 eggs $(95.1 \%)$, in the second - 14,175 eggs $(94.5 \%)$. During
30 days of the experimental period from the control and experimental groups gave 40635, 42435 and 42255 eggs, respectively, and egg production was $90.3 \%, 94.3 \%$ and $93.9 \%$. At the end of the experimental period, the intergroup difference in egg production of the first and second experimental groups was $4 \%$ and $3.6 \%$ compared to the control group.

Table 3

Egg productivity of laying hens in groups $(n=1500)$

\begin{tabular}{lcccc}
\hline \multirow{2}{*}{ Animal groups } & The beginning of the experiment & after 10 days & \multicolumn{2}{c}{ after 30 days } \\
\cline { 2 - 5 } & \multirow{2}{*}{ number of eggs per day } & number of eggs, pcs. & $\begin{array}{c}\text { number of eggs, } \\
\text { pcs. }\end{array}$ & $\begin{array}{c}\text { for laying hens/eggs, } \\
\text { pcs. }\end{array}$ \\
\hline Control & 1431 & 14070 & 40635 & 27.09 \\
Experimental 1 & 1429 & 14265 & 42435 & 28.29 \\
Experimental 2 & 1425 & 14175 & 42255 & 28.17 \\
\hline
\end{tabular}

It is known that the blood parameters of poultry, in particular of laying hens, depends on many factors (physiological condition, age of the poultry, ration, productivity period, etc.). We studied the main parameters of blood, which reflect the state of metabolic processes in the poultry body and are diagnostic criteria for liver pathology.

According to the results of biochemical study of the blood serum of laying hens after administration of hepatoprotectors (after 10 days) in a control, first and second experimental groups, it was established that the content of total protein was $70.7 \pm 0.64 \mathrm{~g} / \mathrm{L} ; 66.7 \pm 0.48 \mathrm{~g} / \mathrm{L}$ and $67.1 \pm 0.68 \mathrm{~g} / \mathrm{L}$, respectively. This parameter was $6 \%$ lower in the first experimental group and $5.4 \%$ in the second comparing to the control group. The content of albumins in the first experimental group was the highest, $3.8 \%$ higher compared to the control group. In the second experimental group there were no probable changes in this indicator $(0.3 \%, \mathrm{P}>0.5)$. After 10 days of hepatoprotectors adminisration, the total cholesterol content was $17.4 \%$ lower in the first experimental group and $8 \%$ lower in the second comparing to the control group. The activity of the hepatospecific enzyme AST in the experimental groups had slight fluctuations and probably did not change (Table 4). In contrast, ALT activity was $25.3 \%$ lower in the experimental groups comparing to the control group. The concentration of uric acid in the serum was $4.2 \%$ lower in the first experimental group comparing to the control group and $3.5 \%$ lower compared to the second experimental group. The urea content in the second experimental group did not differ from the average value of this parameter in the second experimental group. In the first experimental group, it was $15.8 \%$ higher.

\section{Table 4}

Biochemical analysis of blood serum of laying hens $(\mathrm{M} \pm \mathrm{m}, \mathrm{n}=30)$

\begin{tabular}{|c|c|c|c|c|c|c|c|c|c|}
\hline \multirow[b]{2}{*}{ Group } & \multirow[b]{2}{*}{$\begin{array}{l}\text { The term of } \\
\text { experiment }\end{array}$} & \multirow[b]{2}{*}{$\begin{array}{l}\text { Biometric } \\
\text { indicator }\end{array}$} & \multicolumn{7}{|c|}{ Parameters } \\
\hline & & & $\begin{array}{c}\text { Total } \\
\text { protein, } \mathrm{g} / \mathrm{L}\end{array}$ & Albumin, \% & $\mathrm{AST}, \mathrm{U} / \mathrm{L}$ & ALT, U/L & $\begin{array}{c}\text { Total choles- } \\
\text { terol, } \\
\mathrm{mmol} / \mathrm{L}\end{array}$ & $\begin{array}{l}\text { Uric acid, } \\
\mathrm{mmol} / \mathrm{L}\end{array}$ & $\begin{array}{l}\text { Urea, } \\
\mathrm{mmol} / \mathrm{L}\end{array}$ \\
\hline \multirow{2}{*}{ Control } & \multirow{2}{*}{ in 10 days } & Lim & $65.5-76.3$ & $32-41.8$ & $165.1-202.0$ & $7.9-10.1$ & $1.9-3.4$ & $338.7-540.5$ & $1.7-2.2$ \\
\hline & & $\mathrm{M} \pm \mathrm{m}$ & $70.7 \pm 0.64$ & $37.1 \pm 0.56$ & $182.3 \pm 1.85$ & $9.0 \pm 0.13$ & $2.7 \pm 0.07$ & $424.6 \pm 14.02$ & $1.9 \pm 0.03$ \\
\hline \multirow[b]{2}{*}{$\begin{array}{l}\text { Experi- } \\
\text { mental } 1\end{array}$} & \multirow[b]{2}{*}{ in 10 days } & Lim & $61.2-70.3$ & $34.8-41.8$ & $168.6-189.3$ & $10.2-13.5$ & $1.9-2.7$ & $367-513.6$ & $1,7-2,6$ \\
\hline & & $\mathrm{M} \pm \mathrm{m}$ & $\begin{array}{c}66.7 \pm 048 \\
\text { ooo }\end{array}$ & $\begin{array}{c}38.5 \pm 0.37 \\
\mathrm{o}\end{array}$ & $\begin{array}{c}177.5 \pm 1.3 \\
\mathrm{o}\end{array}$ & $\underset{\text { ooo }}{11.9 \pm 0.18}$ & $\begin{array}{c}2.3 \pm 0.05 \\
\text { ooo }\end{array}$ & $\begin{array}{c}407.6 \pm 7.74 \\
\text { oo }\end{array}$ & $\begin{array}{c}2.2 \pm 0.06 \\
\text { ооо }\end{array}$ \\
\hline \multirow{2}{*}{$\begin{array}{l}\text { Experi- } \\
\text { mental } 2\end{array}$} & \multirow[b]{2}{*}{ in 10 days } & Lim & $61.2-72.0$ & $33.5-40.2$ & $158.4-198.5$ & $10.6-13.9$ & $1.9-2.9$ & $333.7-549$ & $1.3-2.3$ \\
\hline & & $\mathrm{M} \pm \mathrm{m}$ & $67.1 \pm 0.68$ & $37.0 \pm 0.41$ & $178.6 \pm 2.52$ & $\begin{array}{c}11.9 \pm 0.19 \\
\text { ooo }\end{array}$ & $\underset{\mathrm{o}}{2.5 \pm 0.05}$ & $421.7 \pm 10.31$ & $1.9 \pm 0.05$ \\
\hline
\end{tabular}

Note: ${ }^{\circ}-\mathrm{P}<0.05 ;{ }^{\text {oo }}-\mathrm{P}<0.01 ;{ }^{\circ 00}-\mathrm{P}<0.001-$ compared to the parameters of control group

Thus, the use of drugs Hep-A-Stress and Hepasan-VS on the 10th day of the experiment did not significantly affect protein homeostasis and functional state of the liver.
To control the prophylactic efficacy of hepatoprotectors, a repeated study of poultry was conducted with analysis of 
biochemical parameters of the blood serum of laying hens after 30 days from the start of drugs use (254 days).

Blood proteins perform numerous functions: maintaining the level of oncotic pressure, blood $\mathrm{pH}$, blood cation levels, play an important role in the formation of immunity (Sharonina et al., 2016). Albumins are formed in hepatocytes, globulins - in cells of the reticuloendothelial system of the bone marrow and reticuloendothelial (Kupffer or stellate) cells of the liver. Therefore, the increase or decrease in serum protein largely depends on the condition of the liver (Thomson et al., 2003; Trott et al., 2014).

At the beginning of the study, statistically significant differences between the parameters of the content of total protein in the serum of the control and experimental groups were not found (Table 5). This parameter ranged from 68.2 to $69.4 \mathrm{~g} / \mathrm{L}$. Thirty days after drug administration, the content of serum total protein of laying hens of the control group increased on $2.3 \%(\mathrm{P}>0.1)$ and amounted to $71.0 \pm 0.46 \mathrm{~g} / \mathrm{L}$, indicating a violation of protein synthesis and development of dystrophic processes in the liver. In the first and second experimental groups, this indicator $(\mathrm{P}<0.001)$ decreased on $21.4 \%$ and $18.9 \%$ compared with animals before drugs administration and on $26.3 \%$ and $23.3 \%(\mathrm{P}<0.001)$ compared to the control group after administration.

The decrease of the content of total protein in the blood serum of laying hens of the experimental groups was due to an increase in the content of albumins and a decrease in globulin fractions. In the first and second experimental groups, the albumin content increased on $5.7 \%(\mathrm{P}<0.001)$ and on $3 \%(\mathrm{P}<0.05)$ compared to parameters before using drugs. This parameter was also higher in laying hens of the experimental groups on $5.4 \%(\mathrm{P}<0.001)$ and on $2.2 \%$ $(\mathrm{P}<0.05)$ compared to poultry of the control group.

\section{Table 5}

The content of serum total protein $(\mathrm{g} / \mathrm{L})$ and it fractions $(\%)$ in laying hens $(\mathrm{M} \pm \mathrm{m}, \mathrm{n}=30)$

\begin{tabular}{|c|c|c|c|c|c|c|c|}
\hline \multirow{3}{*}{ Group } & \multirow{3}{*}{$\begin{array}{c}\text { The term of exper- } \\
\text { iment }\end{array}$} & \multirow{3}{*}{$\begin{array}{l}\text { Biometric } \\
\text { indicator }\end{array}$} & \multicolumn{5}{|c|}{ Parameters } \\
\hline & & & \multirow{2}{*}{$\begin{array}{l}\text { Total protein, } \\
\mathrm{g} / \mathrm{L}\end{array}$} & \multirow{2}{*}{$\begin{array}{c}\text { Albumin, } \\
\%\end{array}$} & \multicolumn{3}{|c|}{ Globulins, \% } \\
\hline & & & & & $\alpha 1$ & $\begin{array}{ll}\alpha 2 & \beta \\
\end{array}$ & $\gamma$ \\
\hline \multirow[t]{2}{*}{ Control } & $\begin{array}{l}\text { The beginning of } \\
\text { the experiment }\end{array}$ & $\mathrm{M} \pm \mathrm{m}$ & $69.4 \pm 0,84$ & $37.6 \pm 0.41$ & $5.7 \pm 0.46$ & $12.3 \pm 0.33 \quad 14.8 \pm 0.64$ & $29.7 \pm 0.74$ \\
\hline & in 30 days & $\mathrm{M} \pm \mathrm{m}$ & $71.0 \pm 0.46$ & $37.1 \pm 0.25$ & $8.8 \pm 0.14$ & $12.2 \pm 0.11 \quad 19.1 \pm 0.21$ & $22.8 \pm 0.25$ \\
\hline \multirow{2}{*}{$\begin{array}{l}\text { Experi- } \\
\text { mental } 1\end{array}$} & $\begin{array}{l}\text { The beginning of } \\
\text { the experiment }\end{array}$ & $\mathrm{M} \pm \mathrm{m}$ & $\begin{array}{l}68.2 \pm 0.84 \\
* * *\end{array}$ & $37.0 \pm 0.24$ & $8.0 \pm 0.47$ & $11.4 \pm 0.4620 .7 \pm 0.56$ & $22.9 \pm 0.85$ \\
\hline & in 30 days & $\mathrm{M} \pm \mathrm{m}$ & $\underset{\text { ооо }}{56.2 \pm 0.58}$ & $\begin{array}{c}39.1 \pm 0.24 \\
\text { ooo } * * *\end{array}$ & $6.4 \pm 0.28$ & $11.5 \pm 0.1921 .6 \pm 0.38$ & $21.5 \pm 0.37$ \\
\hline \multirow{2}{*}{$\begin{array}{l}\text { Experi- } \\
\text { mental } 2\end{array}$} & $\begin{array}{l}\text { The beginning of } \\
\text { the experiment }\end{array}$ & $\mathrm{M} \pm \mathrm{m}$ & $\begin{array}{l}68.5 \pm 0.76 \\
* * *\end{array}$ & $36.8 \pm 0.37$ & $9.9 \pm 0.47$ & $13.6 \pm 0.72 \quad 18.7 \pm 0.63$ & $21.0 \pm 0.37$ \\
\hline & in 30 days & $\mathrm{M} \pm \mathrm{m}$ & $\underset{\text { oo }}{57.6} \pm 0.66$ & $\begin{array}{c}37.9 \pm 0.20 \\
\quad \mathrm{o} *\end{array}$ & $8.2 \pm 0.15$ & $11.5 \pm 0.1820 .7 \pm 0.15$ & $21.7 \pm 0.30$ \\
\hline
\end{tabular}

Note: ${ }^{*}-\mathrm{P}<0.05 ; *_{-} \mathrm{P}<0.01 ; * * *_{-} \mathrm{P}<0.001-$ compared to the parameters of group before giving hepatoprotectors; ${ }^{\circ}-\mathrm{P}<0.05$; ${ }^{\text {oo }}-\mathrm{P}<0.01 ;{ }^{\text {ooo }}-\mathrm{P}<0.001-$ compared to the parameters of control group

It is important to note that 30 days after the use of hepatoprotectors, an increase in total protein and albumin content in the experimental groups indicates a positive effect of drugs on the formation of liver protein synthesis.

Evaluation of liver function was performed by studying hepatospecific serum enzymes - alanine and aspartate aminotransferase activity. It was established that the activity of alanine aminotransferase in the blood of laying hens of the control group at the beginning of the experiment was $9.5 \pm 0.25 \mathrm{U} / \mathrm{L}$ (Fig. 1). During the experimental period, a slight increase (on $13.7 \%, \mathrm{P}<0.01$ ) of the activity of this enzyme in the blood of this group to $10.8 \pm 0.23 \mathrm{U} / \mathrm{L}$ was observed. It should be noted positive changes in ALT in the serum of experimental groups. This is evidenced by a decrease in this parameter in the first experimental group after administration of drugs on $43.7 \%$ and $24.1 \%(\mathrm{P}<0.001)$ compared to the control group. A similar tendency was found in the second experimental group, where the activity of this parameter decreased on $23.4 \%(\mathrm{P}<0.001)$ after administration of drugs and on $14.9 \%(\mathrm{P}<0.001)$ compared to the control group.

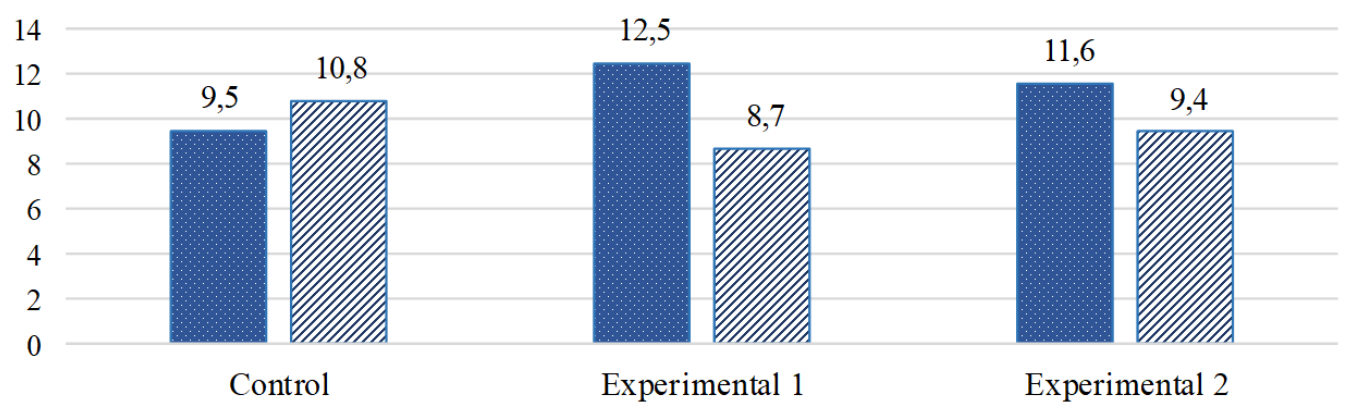

The beginning of the experiment $\square$ In 30 days

Fig. 1. Activity of ALT in the blood serum before and 30 days after using hepatoprotectors $(U / L, n=30)$ 
The activity of AST had a similar tendency (Fig. 2). It was found that this parameter in the serum of the control group after administration of drugs had insignificant changes and increased on $3.3 \%(\mathrm{P}<0.01)$. Thirty days after drugs administration, AST activity decreased in the first and sec- ond experimental groups on $10.7 \%(\mathrm{P}<0.001)$ and on $7.7 \%(\mathrm{P}<0.01)$, respectively. Also, this parameter in the experimental groups was lower compared to the control group after administration of drugs on $11.9 \%$ and $10.1 \%$ $(\mathrm{P}<0.001)$ respectively.

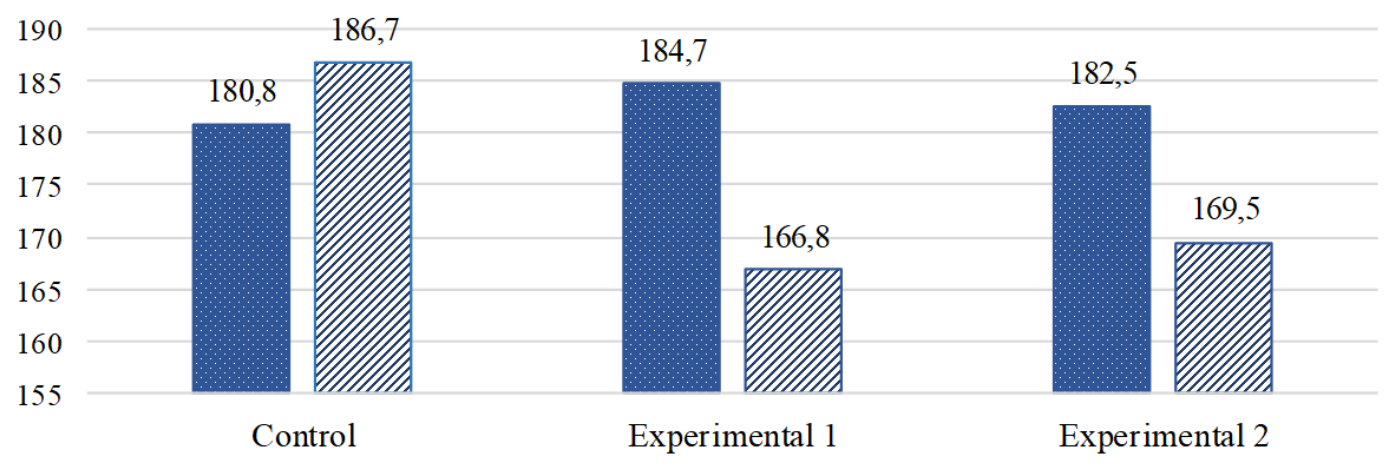

The beginning of the experiment $\square$ In 30 days

Fig. 2. Activity of AST in the blood serum before and 30 days after using hepatoprotectors $(U / L, n=30)$

The use of hepatoprotectors reduced the activity of ALT and AST in the serum of laying hens of experimental groups, which indicates the stabilization of cellular structures of hepatocytes, in particular mitochondrial and cytosolic.

One of the important parameters of lipid metabolism is cholesterol. In first blood sampling (the beginning of the experiment) its level in the control group was $2.4 \pm 0.07 \mathrm{mmol} / \mathrm{L}$, in the first experimental group $1.9 \pm 0.04 \mathrm{mmol} / \mathrm{L}$ and in the second $-2.1 \pm 0.04 \mathrm{mmol} / \mathrm{L}$ (Fig. 3). In 30 days after administration of hepatoprotectors the cholesterol content of the first experimental group con- siderably increased, on $42.1 \%(\mathrm{P}<0.001)$ compared to the parameter before giving the drugs of the same group and on $35 \%(\mathrm{P}<0.001)$ compared to the control group after administration of drugs. A similar tendency was observed in the second experimental group. The level of total cholesterol was $23.8 \%$ higher and $30 \%$ higher $(\mathrm{P}<0.001)$, respectively. The difference between the average values of this parameter of the experimental groups after drug administration was $3.8 \%(\mathrm{P}>0.1)$. The increase of cholesterol content in the experimental groups is probably due to increased bile function, which is key in lipid metabolism.

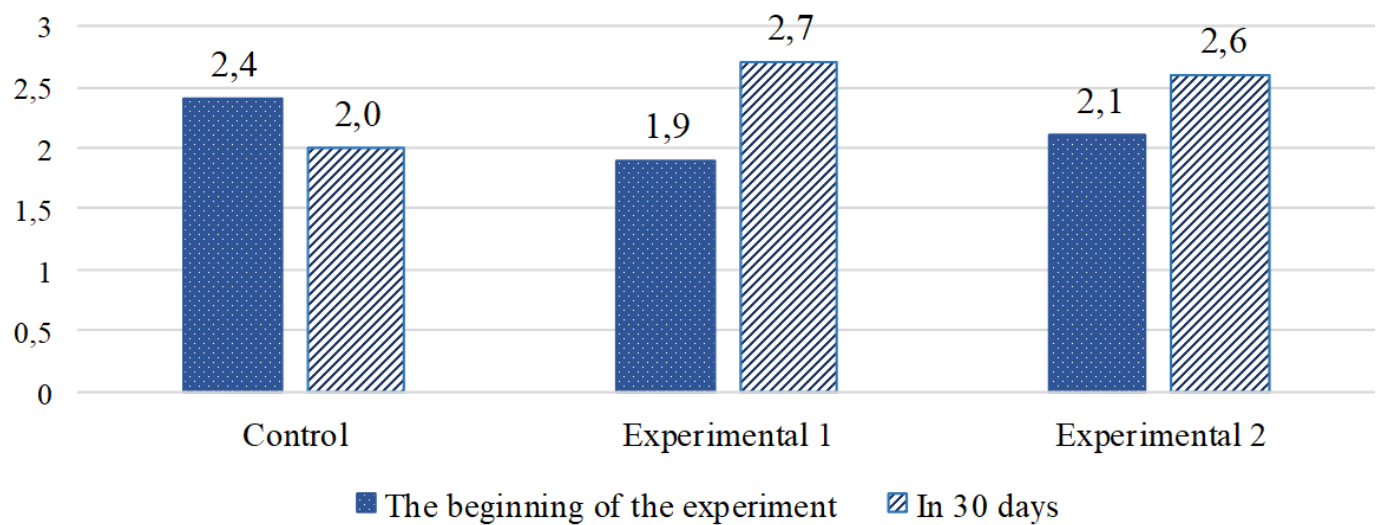

Fig. 3. The cholesterol level in the blood serum before and 30 days after using hepatoprotectors $(\mathrm{mmol} / \mathrm{l}, \mathrm{n}=30)$

The content of serum uric acid of the control group before using hepatoprotectors was $412.5 \mu \mathrm{mol} / \mathrm{L}, 30$ days later $-427.0 \pm 7.98 \mu \mathrm{mol} / \mathrm{L}(+3.5 \%, \mathrm{P}>0.1)$. The opposite dynamics was observed in the experimental groups (Fig. 4). In 30 days after the use of drugs in the first and second experimental groups, the content of uric acid decreased on $14.6 \%$ $(\mathrm{P}<0.01)$ and $18.8 \%(\mathrm{P}<0.05)$ compared to the beginning of the experiment and was lower on $13.7 \%(\mathrm{P}<0.01)$ and $8.2 \%(\mathrm{P}>0.1)$ compared to the control group in the same selection.
It should be noted that the content of serum urea in the control group before and after 30 days use of hepatoprotectors did not differ $(\mathrm{P}>0.5)$ (Fig. 5). After administration of drugs, this parameter increased on $19 \%(\mathrm{P}<0.001)$ and on $10.5 \%(\mathrm{P}<0.05)$ in the first and second experimental groups. An increase in urea content was also found in the experimental groups after the use of hepatoprotectors compared to the control group at the same age (in first experimental - on $25 \%(\mathrm{P}<0.001)$ and second experimental - on $5 \%(\mathrm{P}>0.1))$. These changes indicate an increase in the intensity of protein metabolism. 


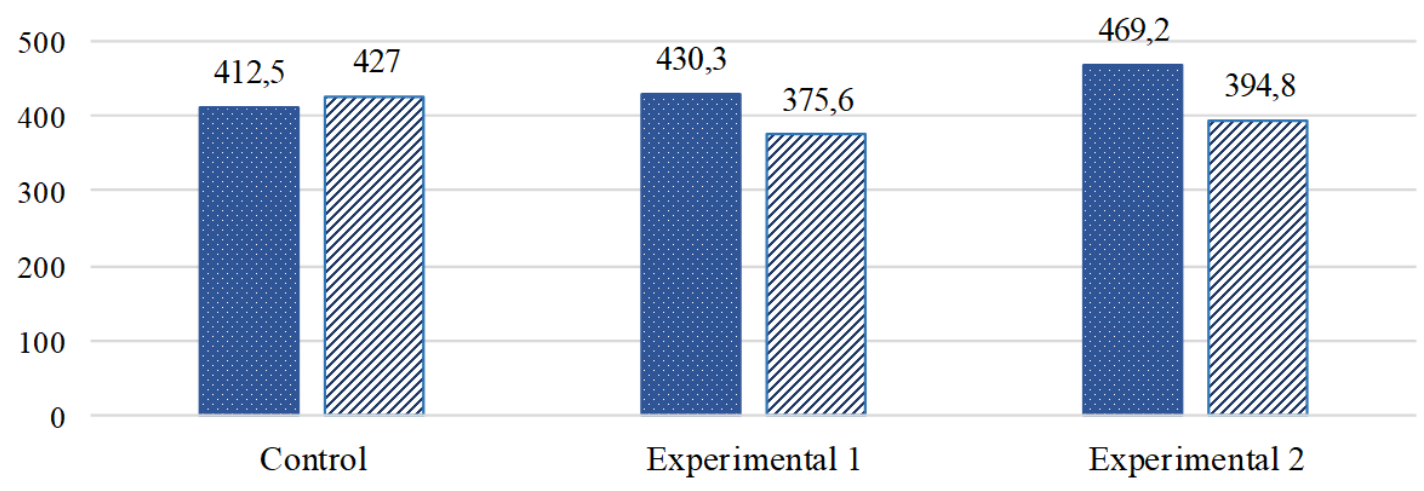

The beginning of the experiment $\square$ In 30 days

Fig. 4. The content of serum uric acid before and 30 days after using hepatoprotectors $(\mu \mathrm{mol} / 1, \mathrm{n}=30)$

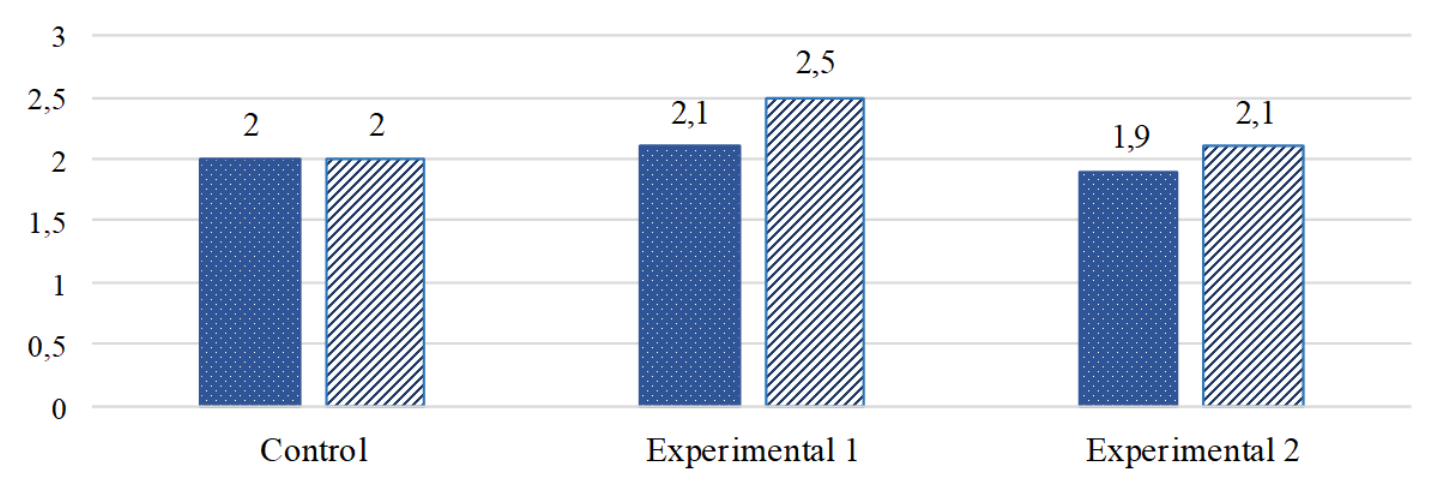

The beginning of the experiment $\square$ In 30 days

Fig. 5. The content of serum urea before and 30 days after using hepatoprotectors $(\mathrm{mmol} / \mathrm{l}, \mathrm{n}=30)$

\section{Discussion}

Analyzing the data of scientific publications, we found that since the $1950 \mathrm{~s}$, extensive research has been conducted on the etiological factors and prevention of avian hepatosis, especially in laying hens. However, these issues are still not fully understood (Shini \& Wayne, 2009; Kuz'minova et al., 2014).

Prevention of non-contagious pathologies of poultry associated with metabolic disorders, in particular hepatosis of laying hens is a priority for veterinary medicine. This is possible due to the use of vitamin, hepatoprotective, antistress and other drugs (Burkov \& Scherbakov, 2012; Katyukha et al., 2017).

Currently, hepatoprotectors are widely used as a preventive measure that helps maintain the structural integrity and functional activity of the liver in the stressful conditions of industrial production of eggs and poultry meat (Surai, 2019). These drugs provide intensive growth, development and high productivity of poultry. Characterizing the mechanism of action of hepatoprotectors, it should be noted that these drugs affect the pathogenesis, not the cause of the disease. The pathogenesis of liver pathologies is based on damage of cellular elements (mainly hepatocytes), which leads to dysfunction, dystrophic changes, inflammation, cytolysis, necrosis or fibrosis (Avdosieva et al., 2014).

Two types of hepatoprotectors were used in our research. The composition of the preparation Hep-A-Stress includes carnitine hydrochloride, D, L methionine, sorbitol, choline chloride, magnesium sulfate heptahydrate. The content of active substances of the preparation Hepasan-VS - Lcarnitine hydrochloride, sorbitol, choline chloride, magnesium sulfate heptahydrate, betaine hydrochloride, L-arginine.
The main active ingredient of used hepatoprotectors is a carnitine (Yakovleva et al., 2011). It is known that it is partially synthesized in the body and performs various functions (antioxidant, anti-inflammatory, energy conversion, lipid lowering, mitochondrial regulator, activation of vitamins, membrane stabilization, protection against apoptosis, glucose homeostasis). However, its main hepatoprotective effect is manifested at the level of vitamins and transcription factors (Surai, 2019). Carnitine is a component of carnitine transferase, which transports the products of hydrolysis of fats - fatty acids in the mitochondria of hepatocytes, where they are subjected to $\beta$-oxidation with the formation of acetic acid and its subsequent condensation with oxaloacetic acid, citric acid is formed, which enters the reaction of the tricarbonate cycle.

Choline in hepatocytes reacts with fat, choline phosphatides are formed, which provide a constant outflow of fatty substances from the liver into the bloodstream and prevent the development of fatty dystrophy of hepatocytes. Thus, choline has a lipotropic effect.

The choline molecule has labile methyl groups required for many tissue synthesis reactions. However, they are only used if there is sufficient number of methionine. In addition, methionine affects the disposal of toxins, slows the deposition of neutral fat in the liver, has a lipotropic effect (removal of excess fat from the liver) (Lemesheva et al., 2002).

Thus, the components of the drugs Hep-A-Stress and Hepasan-VS L-carnitine, choline chloride and methionine have a positive effect on the structure of hepatocytes and the functional state of the liver as a whole. 


\section{Conclusions}

The use of hepatoprotectors Hep-A-Stress and HepasanVS stimulate metabolism and has a positive effect on blood parameters in laying hens. It should be noted that the effect of drugs on the body of the bird is slow, as evidenced by insignificant changes in serum biochemical analysis after 10 days of the experiment. The prophylactic effect of hepatoprotectors was established after 30 days of their use. Namely, a positive effect on protein synthesis, stabilization of cellular structures of hepatocytes and enhancement of bile secretion. The use of hepatoprotectors also had a positive effect on the poultry preservation and egg production of laying hens from the experimental groups.

\section{References}

Avdosieva, I. K., Temnenko, S. M., Kalinovskaya, L. V., \& Zdolini, S. O. (2014). The efficiency of hepatoprotector Hepabialkarnitin in growing broilers. Scientific Messenger of Lviv National University of Veterinary Medicine and Biotechnologies named after S. Z. Gzhytsky, 16, 3(60), 2, 3-11 (in Ukrainian).

Bessarov, B. F., Mel'nykova, Y. Y., Sushkova, N. K., \& Sadchykova, S. Ju. (2009). Diseases of birds [study guide, 2nd edition]. St. Petersburg: Lan (in Russian).

Burkov, P. V., \& Scherbakov, P. N. (2012). The effect of "Geprim for chickens" on the safety and biochemical parameters of blood serum. Bulletin of Altai State Agrarian University, 5(91), 90-92 (in Russian).

Dunets, V. Y., \& Slivinska, L. G. (2017). The prevention of liver disease in laying hens. Scientific Messenger of Lviv National University of Veterinary Medicine and Biotechnologies named after S. Z. Gzhytsky, 19(73), 55-60. doi: 10.15421/nvlvet7312 (in Ukrainian).

Dunets, V. Y., \& Slivinska, L. G. (2018). Clinical syndromatic of laying hens of breed "Lohmann Brown" in the conditions of farm. Scientific Messenger of Lviv National University of Veterinary Medicine and Biotechnologies named after S. Z. Gzhytsky, 20(83), 341-346. doi: 10.15421/nvlvet8368 (in Ukrainian).

Dunets, V. Y., \& Slivinska, L. G. (2018). The functional condition of the liver in laying hens under hepatosis. The animal biology, 20(3), 24-29. doi: 10.15407/animbiol20.03.024 (in Ukrainian).

Ermashkevich, E. I., \& Kletikova, L.V. (2016). Evaluation of fitokompozitions in chickens with protein liver disease by biochemical blood tests. Orel State Gazette, 6(62), 112-117. doi: $10.15217 / 48484$ (in Russian).

Ezhkov, V. O. (2006). Features of metabolic disorders in chickens in industrial conditions poultry breeding. Mater. International NK on the pathophysiology of animals, 57-58 (in Russian).

Kal'berg, N. A., \& Sadovnykov, N. V. (2010). The role of the liver in metabolism. Effective poultry farming, 10(70), 39-41 (in Russian).

Katyukha, S. M., Sachuk, R. M., Sousse, G. V., Magrelo, N. V., \& Tverdiy, V. M. (2017). New Vitamin and Mineral Preparation "BTF Plus": Efficiency of Use in the Diet of Broiler Chickens in the Conditions of Personal Farming. Veterinary biotechnology, 30, 89-94 (in Ukrainian).

Kochish, I. I., Petrash, M. G., \& Smirnov, S. B. (2004). Poultry. M.: Kolos. (in Russian)

Kuz'minova, E. V., Semenenko, M. P., Starikova, E. A., Tjapkina, E. V. \& Fersunin, A. V. (2014). Prospects for expanding the range of hepatoptitectors application in veterinary. Scientific Messenger of Kuban State Agrarian University, 102(08), 787797 (in Russian).

Lemesheva, M. M., Aisobari, E. E., \& Yurchenko, V. V. (2002). Efficiency of using complex feed additives in poultry farming. Bulletin of agrarian science, 42-44 (in Ukrainian).
Melnyk, A. Y. (2014). Prevention of hepatic dystrophy in broiler chickens using the drugs Carnivet L and Vigorpol. Scientific Messenger of Lviv National University of Veterinary Medicine and Biotechnologies named after S. Z. Gzhytsky, 16, 3(60), 235-245 (in Ukrainian).

Melnyk, A. Y. (2015). Analysis and prospects of Ukraine poultry breeding, distribution and classification of poultry metabolic diseases. Scientific Messenger of Veterinary Medicine. Bila Tserkva, 2, 67-73 (in Ukrainian).

Melnyk, A. Y. (2017). Some indicators of protein-lipid metabolism and functional state of the liver in broiler chickens using the drug "Alphabet for animals". Scientific Messenger of Veterinary Medicine, 2, 69-78 (in Ukrainian).

Melnyk, A. Y., \& Ponomar, S. I. (2014). Prevention hepatodystrophy in broiler chickens with using drugs Karnivet L and Vihorpol. Scientific Messenger of LNU of Veterinary Medicine and Biotechnologies. Series: Veterinary Sciences, 16(3), 235244 (in Ukrainian).

Ostapyuk, A., \& Gutyj, B. (2019). Influence of cadmium sulfate at different doses on the functional state of the liver of laying chicken. Scientific Messenger of Lviv National University of Veterinary Medicine and Biotechnologies. Series: Veterinary sciences, 21(94), 103-108. doi: 10.32718/nvlvet9419 (in Ukrainian).

Sharonina, N. V., Mukhitov, A. Z., \& Shishkov, N. K. (2016). Some indicators of metabolism in laying hens when feeding soy okara. Bulletin of the Ulyanovsk State Agricultural Acade$m y, 4(36)$, 68-71. doi: 10.18286/1816-4501-2016-4-68-71 (in Russian).

Shini, S., \& Wayne, L. (2009). Occurrence and control of fatty liver haemorrhagic syndrome (FLHS) in caged hens. Australian egg corporation limited. A report for the Australian egg corporation limited, 105, 1-62.

Sokolov, M. N. (2016). On the use of hepatoprotectors in poultry farming. Young scientist, 20, 110-113. https://moluch.ru/archive/124/34137 (in Russian).

Sokolov, V. G., \& Ivannikov, S. M. (2013). Clinical and pathomorphological features of diagnostics hepatosis chickens. Scientific works of the southern branch of the National University of Life and Environmental Sciences of Ukraine "Krim Agrotechnological University". Series: Veterinary science, 155, 232-237 (in Russian).

Surai, P. F. (2019). Vitagenes in poultry production: adaptation to commercially relevant stresses. Modern poultry farming. Scientific production journal, 07-08(200-201), 28-32 (in Ukrainian).

Thomson, A. E., Gentry, P. A., \& Squires, E. J. (2003). Comparison of the coagulation profile of fatty liver haemorrhagic syndromesusceptible laying hens and normal laying hens. British Poultry Science, 44(4), 626-633. doi: 10.1080/00071660310001616228.

Trott, K. A., Giannitti, F., Rimoldi, G., Hill, A., Woods, L., Barr, B., Anderson, M., \& Mete, A. (2014). Fatty liver hemorrhagic syndrome in the backyard chicken: A retrospective histopathologic case series. Veterinary pathology, 51(4), 787-795. doi: 10.1177/0300985813503569.

Yakovleva, L. V., Bezchasnyuk, E. M., Ulesov, A. V., Shapoval, O. N., Khomyakova, L. G., \& Zborovskaya, T. V. (2011). Lcarnitine: properties, drugs, medical use. Ukrainian Journal of Clinical and Laboratory Medicine, 6(2), 17-24 (in Russian).

Yaremchuk, V., Slivinska, L., \& Stronskyi, Y. (2020). Morphological particulars of the liver of laying hens of breed "Lohmann Brown" under hepatosis. Scientific Messenger of LNU of Veterinary Medicine and Biotechnologies. Series: Veterinary Sciences, 22(97), 69-73. doi: 10.32718/nvlvet9712 (in Ukrainian).

Zhang, J., Chen, D., \& Yu, B. (2008). Effect of different dietary energy sources on induction of fatty liver-hemorrhagic syndrome in laying hens. International journal of poultry science, $7(12), 1232-1236$. 